\title{
Prospek Hukum Islam dalam Sistem Hukum Indonesia
}

\author{
Saifuddin
}

\begin{abstract}
The Prospect Of Islamic Law In Indonesia Legal System. Although the majority of Indonesian citizens are Muslims, Islamic law cannot automatically apply in this country. This is because Indonesia is not a religious state and does not make religion as the state's ideology. This article analyzes the prospects of tranformation of Islamic law into the national legal system. The aim is to find a format that is in accordance with the character of the Indonesian state and does not deviate from state idiology of Pancasila . This study concludes that there are only a few ways to enforce Islamic law in Indonesia without changing the existing state order. First: through a constitution amendment. Islamic law can be transformed into positive law insofar as it is accepted by the legislative body through democratic ways. Second: through the transformation of legal material. This method is carried out by changing the material law based on secular values into a legal product based on Islamic values. Third: through regional autonomy. such as in Aceh, Banten, Madura, and Gorontalo.
\end{abstract}

Keywords: Islamic law, legal politics, Islam in Indonesia

\begin{abstract}
Abstrak: Prospek Hukum Islam dalam Sistem Hukum Indonesia. Kendatipun mayoritas warga negara Indonesia adalah umat Islam, namun hukum Islam tidak dapat secara otomatis berlaku di negeri ini. Hal ini dikarenakan Indonesia bukan negara agama dan tidak menjadikan agama sebagai landasan ideologi negara. Artikel ini menganalisis prospek masuknya hukum Islam dalam sistem hukum nasional. Tujuannya untuk menemukan format yang sesuai dengan karakter negara Indonesia dan tidak menyimpang dari landasan idiil negara yakni Pancasila. Penelitian ini menyimpulkan hanya ada sedikit cara untuk memberlakukan hukum Islam di Indonesia, tanpa mengubah tatanan kenegaraan, yakni (1): melalui amandemen UUD. Ketika ada amandemen konstitusi, hukum Islam bisa saja ditransformasikan menjadi hukum positif sejauh disepakati oleh badan legislatif melalui cara dan prosedur demokratis. Kedua melalui transformasi materi hukum. Cara ini dilaksanakan dengan mengubah hukum materiil yang semula berlandaskan kepada nilainilai sekuler menjadi produk hukum yang berlandaskan nilai-nilai ajaran Islam. Ketiga: melalui otonomi daerah. seperti di Aceh, Banten, Madura, dan Gorontalo.
\end{abstract}

Kata Kunci: hukum Islam, politik hukum, Islam di Indonesia 


\section{Pendahuluan}

Menurut Harun Nasution, hanya ada kurang dari sepuluh persen tepatnya sekitar 5,8 persen kandungan Alquran yang berbicara tentang hukum dan perundang-undangan. Selebihnya Alquran banyak berbicara tentang sejarah umat manusia. ${ }^{1}$ Dari sepuluh persen itu ayat-ayatnya ada yang secara jelas (mubkam atau qathî) menjelaskan tentang suatu hukum, tetapi ada juga yang tidak jelas atau samar (mutasyâbihât atau $d z a n n i ̂)$ menerangkan tentang suatu perkara hukum. ${ }^{2}$

Oleh sebab itu, sebetulnya Alquran ingin memberikan keleluasaan kepada umat Islam untuk mengatur urusan hukum dan perundangundangan yang berkaitan dengan kemaslahatan hidupnya di dunia ini. Karena itu, di beberapa negara muslim tidak ada keseragaman mengenai strategi yang digunakan. ${ }^{3}$

${ }^{1}$ Harun Nasution, Islam Ditinjau dari Berbagai Aspeknya Jilid 1 (Jakarta: Penerbit UIPress, 2013), h. 1.

${ }^{2}$ Terkait pembahasan muhkamat dan mutasyabihat bisa dilihat pada karya A Faroqi. "Analisis Ayat-ayat Mutasyabihat Tafsir al-Munir Karya Wahbah Az-Zuhaili." PhD diss., UIN Walisongo, 2016. Muhammad Anwar Firdausi. "Membincang Ayat-ayat Muhkam dan Mutasyabih." Ulul Albab Jurnal Studi Islam 16, no. 1 (2015): h. 80-88. Nova Yanti. "Memahami Makna Muhkamat dan Mutasyabihat dalam Al-Quran." Al-Ishlah: Jurnal Pendidikan 8, no. 2 (2016): h. 246-256. Hadi Ismail M. "Konsep Tauriyah dalam Memahami Ayat-ayat Mutasyabihat: Studi Analisis Terhadap Ta'wil Ayat-ayat Sifat.” PhD diss., UIN Sunan Gunung Djati Bandung, 2012. Syamsu Nahar. "Keberadaan Ayat Muhkam dan Mutasyabih dalam Al-Quran." Nizhamiyah 6, no. 2 (2016). Sementara terkait ayat qath'i dan dzanni terdapat dalam karya Subhan. "Klasifikasi Ayatayat Hukum (dari Segi Qathi dan Zhanni)." Mazahib 12, no. 2 (2013). Ratu Haika. "Konsep Qath'i dan Zhanni dalam Hukum Kewarisan Islam.” Mazahib 15, no. 2 (2016): h. 182-195. Selain konsep qathi dan dzanni juga disebut dengan ta'aqqulli dan ta'abbudi bisa lihat seperti dalam karya Abdul Qodir Zaelani. "Konsep Ta'aqquli dan Ta’abbudi dalam Konteks Hukum Keluarga Islam.” Asas: Jurnal Hukum dan Ekonomi Islam 6, no. 1 (2014).

${ }^{3}$ Beberapa Negara memiliki keunikan tersendiri dalam perundang-undangannya, terkadang berbeda satu Negara muslim dengan Negara muslim lainnya, bisa dilihat selengkapnya dalam karya Khoiruddin Nasution. Status Wanita di Asia Tenggara: Studi Terhadap Perundang-undangan Perkawinan Muslim Kontemporer di Indonesia dan Malaysia. Vol. 39. INIS, (2002). Khoiruddin Nasution. Islam Tentang Relasi Suami dan Isteri (Hukum Perkawinan I): Dilengkapi Perbandingan UU Negara Muslim. (Yogyakarta: ACAdeMIA, 2004). Hj Djazimah Muqoddas, dan M. SH. Kontroversi Hakim Perempuan pada Peradilan Islam di Negara-negara Muslim. (Yogyakarta: LKiS Pelangi Aksara, 2011). Nasaruddin Umar, dan Direktur Jenderal Bimbingan Masyarakat Islam. "Hukum Keluarga Kontemporer di Negara-negara Muslim." Dalam Makalah Seminar Nasional Hukum Materiil Peradilan Agama antara Cita, Realitas dan Harapan, Hotel Red Top Jakarta, vol. 19. 2010. Tamir Moustafa. "Judging in God's Name: State Power, Secularism, and the Politics of Islamic Law in Malaysia." Oxford Journal of Law and Religion 3, no. 1 (2013): h. 152-167. Farid Sufian Shuaib, Tajul Aris Ahmad Bustami, Mohd Kamal, dan Mohd Hisham. Administration of Islamic Law in Malaysia: Text and Material. Malayan Law Journal, 
Di negara-negara Muslim hubungan antara agama dan negara dalam konteks yang lebih luas dan hubungan antara hukum Islam dan hukum nasional dalam konteks yang lebih sempit memiliki hubungan yang unik dan beragam. Hubungan tersebut kalau disederhanakan paling tidak terdapat tiga corak, yaitu pertama hukum Islam (syari'at) adalah notabene hukum nasional, contohnya adalah negara-negara yang secara jelas menyebut negara Islam dan Undang-Undang Dasarnya adalah syariat Islam seperti Kerajaan Arab Saudi, Republik Islam Iran dan Republik Islam Pakistan, walaupun dalam beberapa hal ketiga negara tersebut juga mengkonversi perundang-undangan selain hukum Islam seperti kasus Arab Saudi dalam hal hukum dagang internasional. ${ }^{4}$

Corak kedua, hukum Islam tidak otomatis menjadi UUD tetapi sebatas menjadi sumber atau bahan dalam pembuatan hukum nasional. Corak kedua inilah yang banyak dianut oleh negeri-negeri Muslim seperti

2001. Mohammad Hashim Kamali. "Punishment in Islamic Law: A Critique of the Hudud Bill of Kelantan, Malaysia." Arab Law Quarterly 13, no. 3 (1998): h. 203-234. Tamir Moustafa. "Islamic Law, Women's Rights, and Popular Legal Consciousness in Malaysia." Law \& Social Inquiry 38, no. 1 (2013): h. 168-188.

${ }^{4}$ Terkait perkembangan hukum Islam di Negara-negara tersebut bisa dilihat selengkapnya dalam karya Azadeh Niknam. "The Islamization of Law in Iran." Middle East Report 29, no. 212 (1999): 17-21. Lawrence E Walsh. "Political Oversight, the Rule of Law, and Iran-Contra." Clev. St. L. Rev. 42 (1994): h. 587. Bagher Larijani, and Farzaneh Zahedi. "Health Promotion, Islamic Ethics and Law in Iran." DARU Journal of Pharmaceutical Sciences Suppl. 1 (2006): h. 7-9. Mosayeb Pahlavani, Davoud Abed, and Farshid Pourshabi. "Investigating the Keynesian View and Wagner's Law on The Size Of Government And Economic Growth In Iran." International Journal of Business and Social Science 2, no. 13 (2011). Jennifer F Cohen. "Islamic Law in Iran: Can It Protect the International Legal Right of Freedom of Religion and Belief." Chi. J. Intl L. 9 (2008): h. 247. Ziba Mir-Hosseini. "8 Sharia and National Law in Iran." Sharia Incorporated (2010): h. 319. Hamlin, Kristan L. Peters. "The Impact of Islamic Revivalism on Contract and Usury Law in Iran, Saudi Arabia, and Egypt." Tex. Int'l LJ 22 (1987): h. 351. Mehrangis Kar. "Schari'a Law in Iran." Radical Islam's Rules: The Worldwide Spread of Extreme Shari'a Law (2005): h. 41-64. Amir Farmanfarma. "Constitutional Law of Iran." The American Journal of Comparative Law (1954): h. 241-247. Mohammad Afzal, and Qaisar Abbas. "Wagners Law in Pakistan: Another Look.” Journal of Economics and International Finance 2, no. 1 (2009): h. 012-019. Rubya Mehdi. The Islamization of the Law in Pakistan (RLE Politics of Islam). (Routledge, 2013). Rubya Mehdi. "The Offence of Rape in the Islamic Law of Pakistan." Women Living under Muslim Laws: Dossier 18 (1997): h. 98-108. Noel J Coulson. "Reform of Family Law in Pakistan." Studia Islamica 7 (1957): $1 \mathrm{~h}$. 35-155. Frank E Vogel. Islamic Law and the Legal System of Saudi: Studies of Saudi Arabia. Vol. 8. Brill, (2000). Sam S Souryal. "The Religionization of A Society: The Continuing Application of Shariah Law in Saudi Arabia." Journal for the Scientific Study of Religion (1987): h. 429-449. Salaheddine Bendak. "Compliance With Seat Belt Enforcement Law in Saudi Arabia." International Journal of Injury Control and Safety Promotion 14, no. 1 (2007): h. 45-48. 
Indonesia, Malaysia, Mesir, Sudan dan lain sebagainya. ${ }^{5}$ Corak ketiga adalah negeri Muslim yang sama sekali mengesampingkan hukum Islam dan hanya mengadopsi sistem hukum sekuler. Corak ketiga ini yang ditempuh oleh Republik Turki.

Dari ketiga corak tersebut corak kedualah yang banyak mendapat perhatian para peneliti karena di samping unik juga memberikan ruang dialog yang kondusif bagi eksistensi umat non-Muslim yang juga merupakan warga negara yang memiliki hak dan kewajiban yang sama. Di antara negeri-negeri Muslim yang menganut corak kedua ini Indonesia adalah contoh yang sangat penting untuk diteliti lebih lanjut karena di negeri yang mayoritas penduduknya Muslim bahkan terbesar di dunia ini berbagai macam agama dan kepercayaan, suku bangsa, etnis, dan budaya bisa hidup rukun berdampingan sebagai satu komunitas bangsa.

Oleh sebab itu, menjadi penting kemudian untuk melihat posisi dan prospek hukum Islam dalam sistem hukum Indonesia. Untuk itu, tulisan ini berusaha menjelaskan pandangan Alquran mengenai hukum dan perundang-undangan sekaligus menjelaskan posisi dan prospek hukum Islam dalam sistem hukum Indonesia mulai dari awal pembentukan negara sampai pasca amandemen UUD 1945 dan diterapkannya undangundang mengenai otonomi daerah yang berimplikasi pada kemunculan banyak Peraturan Daerah (PERDA) syari'ah. ${ }^{6}$

${ }^{5}$ Perkembangan hukum Islam pada Negara-negara tersebut lebih jelas dan lengkapnya bisa dilihat dalam karya Clark B Lombardi. "Islamic Law As A Source of Constitutional Law in Egypt: The Constitutionalization of the Sharia in A Modern Arab State." Colum. J. Transnat'l L. 37 (1998): h. 81. Clark Lombardi. State Law as Islamic Law in Modern Egypt: The Incorporation of the Sharîa into Egyptian Constitutional Law. (Brill, 2006). Fluehr-Lobban, Carolyn. Islamic Law and Society in the Sudan. (Routledge, 2013). Kent Benedict Gravelle. "Islamic Law in Sudan: A Comparative Analysis." ILSA J. Int'l \& Comp. L. 5 (1998): h. 1. Aharon Layish, and Gabriel R. Warburg. The Reinstatement of Islamic law in Sudan Under Numayrî: An Evaluation of A Legal Experiment in the Light of Its Historical Context, Methodology, and Repercussions. (Brill, 2002), h. 31." Fluehr-Lobban, Carolyn. "Islamization in Sudan: A Critical Assessment." Middle East Journal 44, no. 4 (1990): h. 610-623. Anderson, James Norman Dalrymple. "The Modernisation of Islamic Law in the Sudan.” Sudan Law Journal and Reports1960 (1960): h. 292-312.

${ }^{6}$ Perda-perda bernuansa syarih terus mendapat sorotan dan kajian dari berbagai pihak, di antaranya karya Robin Bush. "10 Regional Sharia Regulations In Indonesia: Anomaly Or Symptom?." Expressing Islam: Religious Life and Politics in Indonesia (2008): 174. Sukron Kamil, Andy Agung Prihatna, Karina Helmanita, J. M. Muslim, Ridwan al-Makassary, Aang Abu Bakar, and Tuti Alawiyah. Syariah Islam dan HAM: Dampak Perda Syariah Terhadap Kebebasan Sipil, Hak-hak Perempuan dan Non-Muslim. Center for the Study of Religion and Culture (CSRC) 


\section{Pandangan Alquran mengenai Hukum dan Perundang-Undangan}

Pada pendahuluan sudah dijelaskan bahwa kandungan Alquran tentang hukum dan perundang-undangan hanya sekitar 5,8 persen dari total ayat yang berjumlah sekitar 6.360 ayat. Rincian ayat-ayat hukum dalam Alquran sebagai berikut: ${ }^{7}$

1. Mengenai ibadah salat, puasa, haji, dan lain-lain sebanyak 140 ayat

2. Mengenai hidup kekeluargaan, perkawinan, perceraian, hak waris dan sebagainya, sebanyak 70 ayat.

3. Mengenai hidup perdagangan/perekonomian, jual beli, sewa menyewa, pinjam meminjam, gadai, perseroan, kontrak, dan sebagainya sebanyak 70 ayat.

4. Mengenai soal kriminal sebanyak 30 ayat.

5. Mengenai hubungan Islam dan bukan Islam sebanyak 25 ayat.

6. Mengenai soal pengadilan sebanyak 13 ayat.

7. Mengenai hubungan kaya dan miskin sebanyak 10 ayat.

8. Mengenai soal kenegaraan sebanyak 10 ayat.

Dari 368 ayat itu hanya 228 atau 3 1/2 persen yang mengurus soal hidup kemasyarakatan umat.

UIN Syarif Hidayatullah Jakarta, 2007. Wasisto Raharjo Jati. "Permasalahan Implementasi Perda Syariah dalam Otonomi Daerah." Al-Manahij: Jurnal Kajian Hukum Islam 7, no. 2 (2013): h. 305-318. Candraningrum, Dewi. "Unquestioned Gender Lens in Contemporary Indonesian Shari 'ah-Ordinances (Perda Syariah).” Al-Jami'ah: Journal of Islamic Studies 45, no. 2 (2007): h. 289-320 Dewi. Candraningrum. "Unquestioned Gender Lens in Contemporary Indonesian Shari 'ah-Ordinances (Perda Syariah)." Al-Jami'ah: Journal of Islamic Studies 45, no. 2 (2007): h. 289-320. Pudjo Suharso. "Pro Kontra Implementasi Perda Syariah (Tinjauan Elemen Masyarakat)." AlMawarid 16 (2006). Ahmad Norma Permata. "Perda Syariah Islam, Rekayasa Institusional dan Masa Depan Demokrasi." dalam Jurnal Ijtihad 7, no. 1 (2007). Muhammad Alim. "Perda Bernuansa Syariah dan Hubungannya dengan Konstitusi." Jurnal Hukum Ius Quia Iustum 17, no. 1 (2010): h. 119-142. S. Kamil, and C. S. Bamualim. "Syariah Islam dan HAM: Dampak Perda Syariah terhadap Kebebasan Sipil, Hak-Hak Perempuan, dan Non-Muslim [Shari'a and Human Rights: The Impacts of Local Regulations to the Civil Freedom, the Rights of Women, and non-Muslims]." Jakarta: CSRC UIN Jakarta \& KAS Jakarta (2007). Munawar Ahmad. "Fenomena Perda Syariah: Institutional Identitas pada Tingkat Local State." Jurnal Sosiologi Agama 1, no. 1 (2007). Agus Purnomo. "Politik Hukum Elite Politik Kabupaten Pamekasan Tentang Perda Syariat." Istinbath: Jurnal Hukum Islam IAIN Mataram 13, no. 1 (2013). Ahmad Abrori. "Refleksi teori kritis jurgen habermas atas konsesus simbolik perda syariah." Ahkam: Jurnal Ilmu Syariah 16, no. 1 (2016).

${ }^{7}$ Nasution, Islam Ditinjau dari Berbagai Aspeknya Jilid 1, h. 2. 
Hikmahnya adalah bahwa Alquran tidak ingin mengikat masyarakat yang begitu dinamis sementara hukum adalah alat pengikat bagi masyarakat dalam menata kehidupannya. Dengan demikian, Alquran sebagai kitab pedoman akan tetap shâlih li kulli zamân wa makân.

Sementara penjelasan Alquran mengenai hukum ada tiga bentuk, yaitu: ${ }^{8}$

1. Penjelasan Alquran bersifat sempurna. Dalam hal ini sunnah berfungsi untuk menetapkan makna yang dikandungnya. Misalnya QS. alBaqarah (2): 185 yang berbunyi:

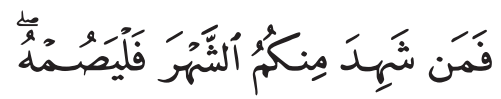

(Karena itu barangsiapa di antara kamu hadir (di negeri tempat tinggalnya) di bulan itu, maka hendaklah ia berpuasa pada bulan itu.').

Begitu juga ayat qazaf (menuduh wanita baik-baik berzina) dan li'an berkaitan dengan suami yang menuduh isterinya berbuat zina. Ayat-ayat tersebut menjelaskan hukuman pelakunya secara sempurna.

2. Penjelasan Alquran bersifat global (mujmal), sedangkan sunnah berfungsi untuk menjelaskannya lebih konkrit. Seperti perintah mendirikan salat, membayar zakat, serta lafaz-lafaz yang tidak jelas maknanya, kecuali setelah dijelaskan oleh sunnah.

3. Alquran hanya menjelaskan pokok-pokok hukum, baik dengan isyarat, mau pun dengan ungkapan langsung, kemudian sunnah merinci hukum tersebut dengan sempurna. Misalnya hukuman hamba sahaya yang disebutkan dalam Q.s. al-Nisa: 25 yang berbunyi:

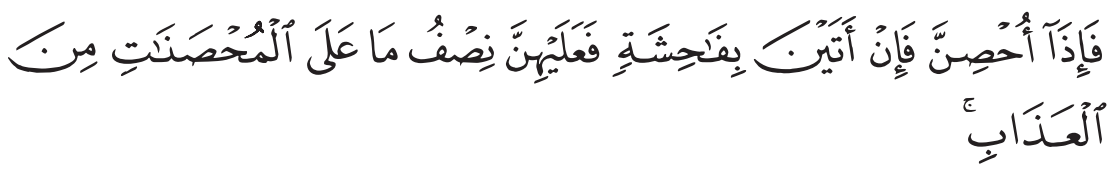

('Dan apabila mereka telah menjaga diri dengan kawin, kemudian mereka mengerjakan perbuatan yang keji (zina), maka atas mereka separo hukuman dari hukuman wanita-wanita merdeka yang bersuami').

Ayat ini mengisyaratkan, bahwa hukuman bagi hamba sahaya adalah separo dari hukuman orang yang merdeka, baik dalam hukuman pidana maupun menyangkut hak-hak hamba sahaya.

${ }^{8}$ David, 'Konsep Hukum dalam Alquran : Keadilan dan Kemanusiaan', Tahkim, 2009. 
Adapun kandungan hukum dalam Alquran dapat dibagi dalam beberapa bagian. Menurut Muhammad Abû Zahrah, hukum-hukum dalam Alquran terbagi dalam beberapa hal. Pertama, ibadah, seperti salat, zakat, puasa, haji, sedekah dengan segala macam dan ragamnya. Kedua, kafarat, yang menjadi bagian dari ibadah sebagai penebus terhadap sebagian dari dosa (kafarat zihar, sumpah dan pembunuhan orang mukmin tanpa sengaja). Ketiga, hukum muamalah. Keempat, hukum keluarga. Kelima, hukum pidana. Keenam, hukum acara (hubungan antara hakim dan pelaku tindak pidana). Ketujuh, perlakuan terhadap non muslim. ${ }^{9}$

Sumber hukum Islam adalah Alquran kemudian Sunnah. Jika tidak diketemukan hukum pada keduanya maka sumber hukum Islam yang ketiga adalah ijma' dan yang keempat adalah qiyas. Sebagian ulama' menyatakan hanya ada tiga yaitu Alquran, Sunnah dan Ijtihad. Hasil penalaran hukum dari sumber-sumber tersebut dikenal dalam sejarah Islam dengan istilah fikih.

Fikih secara istilah didefinisikan dengan ilmu yang mempelajari hukum-hukum syari'ah yang bersifat praksis yang digali dari dalildalilnya yang terperinci. Fikih menurut bentuknya paling tidak ada tiga. Pertama, berupa kitab-kitab kuning yang dikarang oleh para ulama' salaf maupun khalaf. Kedua, berupa fatwa semisal fatwa MUI (Majlis Ulama Indonesia), fatwa Ali Komeini tentang halalnya darah Salman Rusydi dan lain sebagainya. Ketiga, berupa qanun/undang-undang seperti UU No. 1 Tahun 1974 tentang perkawinan, KHI, UU tentang wakaf dan lain-lain. Bentuk yang pertama tidak mengikat sehingga tidak memiliki kekuatan memaksa. Bentuk kedua sedikit terikat kepada orang atau daerah tertentu tapi secara hukum tidak memiliki kekuatan memaksa. Bentuk ketiga terikat dan memiliki kekuatan memaksa.

Bentuk ketiga inilah yang pada era dewasa ini sangat berkembang di negara-negara muslim karena sifatnya yang bisa mengikat umat Islam di negara tersebut, lazimnya disebut fiqh al-qanûn. Fiqh al-qanûn terdiri dari dua kata fiqh dan al-qanûn. Fiqh definisinya sebagaimana yang dijelaskan di atas, sedangkan al-qanûn adalah peraturan, hukum atau undang-undang

\footnotetext{
${ }^{9}$ Muhammad Abu Zahra, Usul Al-Fiqh (Cairo: Dâr al-Fikr al-'Arabi, 1958), h. 55.
} 
seperti qanûn tijâri (hukum dagang), qanûn janâi (hukum pidana), qanûn duwaliy (hukum internasional), qanûn al-murâfáat (hukum acara) qanûn asâsi (undang-undang dasar) dan lain-lain. ${ }^{10}$ Dengan demikian, fiqh alqanûn berarti fikih yang berbentuk undang-undang (positif), memiliki kekuatan memaksa.

Fiqh al-qanûn sebenarnya tidak jauh berbeda dengan kitab-kitab fikih dan pembagian-pembagiannya yang biasa. Akan tetapi fiqh al-qanûn tersebut dipisah-pisahkan satu sama lain dengan pasal-pasal yang memakai nomor berturut-turut seperti halnya dengan kitab undang-undang hukum positif, supaya mudah mencari dan melihat ketentuan-ketentuannya. Contohnya KHI (Kompilasi Hukum Islam) yang terdiri dari buku I berisi hukum perkawinan, buku II berisi hukum kewarisan, dan buku III berisi hukum perwakafan serta terdiri dari 229 pasal.

Manfaat adanya fiqh al-qanûn adalah bahwa di antara beberapa pendapat dalam satu masalah hanya satu saja yang dipakai, tanpa menyebutkan bermacam-macam pendapat seperti lazimnya kitab-kitab fikih. Cara seperti ini biasa dipakai dalam formulasi undang-undang, karena undang-undang tidak boleh memuat ketentuan-ketentuan yang tidak harus dilaksanakan. ${ }^{11}$

Di samping itu, adanya fiqh al-qanûn memungkinkan masuknya nilai-nilai lokal (local wisdom) ke dalam materi fiqh al-qanûn yang sedang disusun. Suatu contoh beberapa produk hukum dalam KHI yang tidak berasal dari hukum Islam (secara murni) tetapi merupakan penyerapan dari budaya lokal semisal adanya harta gono gini, status anak sah yang tidak hanya merupakan hasil dari perkawinan yang sah tetapi juga anak yang lahir di dalam perkawinan yang sah, sehingga nantinya selain produk perundang-undangan tersebut bisa membumi juga memiliki ciri khas lokal.

Munculnya fiqh al-qanûn sendiri sangat populer pada masa Turki Usmani yaitu dengan penyusunan undang-undang perdata Usmani

${ }^{10}$ Ahmad Warson Munawwir, Kamus Al-Munawwir Arab-Indonesia Terlengkap, (Surabaya: Pustaka Progressif, 1997), h. 1165.

${ }^{11}$ Ahmad Hanafi, Pengantar dan Sedjarah Hukum Islam (Bulan Bintang, 1970), h. 220. 
(al-Qanûn Al-Madâni Al-Adliyah), walaupun sebenarnya menurut W. Montgomery beberapa bagian fikih telah disusun dalam bentuk undangundang sejak dari masa Nabi Saw. masih hidup. Undang-undang yang merupakan UUD Islam pertama itu, oleh Ibnu Hisyam diberi nama dengan Kitabun Nabi. Kemudian diterjemahkan ke dalam bahasa Inggris dengan nama The Constitusion of Madina pada tahun 1956 oleh Montgomery sendiri dan pada tahun 1961 di-Indonesia-kan oleh $\mathrm{H}$. Zainal Abidin Ahmad, dengan nama piagam Nabi Muhammad Saw. ${ }^{12}$

Cara yang ditempuh Turki Usmani ini juga diikuti oleh Mesir, Syiria, Irak, Tunisia, Indonesia dan negara lainnya seperti penyusunan perundang-undangan tentang al-Ahwal al-Syakhsyiyyah, wakaf, waris, wasiat dan lainnya, disesuaikan dengan kebutuhan masa kini, dan perubahan kondisi dan situasi (Al-Ahwal wad Duruf). ${ }^{13}$

Figh al-qanûn ini, karena merupakan hasil ijtihâd jamầi tentunya berasal dari pendapat-pendapat, pendekatan, metodologi dan mazhab yang berbeda. Mengenai hal ini syekh Faraj al-Sanhuri mengatakan bahwa para pembuat undang-undang wakaf tidak terikat dengan ketentuanketentuan mazhab empat atau ketentuan-ketentuan mazhab tertentu. Mereka mengambil dari setiap mazhab apa yang dipandang perlu untuk diambil. Kalau ketentuan-ketentuan undang-undang tersebut telah merupakan campuran hukum fikih yang tidak didapati pada salah satu mazhab tersebut, maka hal ini merupakan akibat logis dari sistem pemilihan dari mazhab-mazhab tersebut. Akan tetapi, tidak didapati satu ketentuanpun yang asing sama sekali dari fikih Islam, dan tiap-tiap ketentuan daripadanya tidak lebih daripada pendapat yang dikemukakan oleh seorang imam, kaum muslimin, atau suatu pikiran yang pernah dikatakan oleh seorang fâqih, atau lebih daripada susunan pendapat dan pikiran-pikiran tersebut. ${ }^{14}$

Di Indonesia, fiqh al-qanûn ini mewujud dalam beberapa peraturan perundang-undangan. Sebetulnya merupakan murni hukum Islam tapi hebatnya tidak hanya berlaku bagi umat Islam saja tetapi juga berlaku

\footnotetext{
${ }^{12}$ Husni Rahiem, Perkembangan Ilmu Figh di Dunia Islam, (Jakarta: Depag RI, 1991), h. 54.

13 Rahiem, Perkembangan Ilmu Figh di Dunia Islam, h. 23.

${ }^{14}$ Hanafi, Pengantar dan Sedjarah Hukum Islam, h. 179-180.
} 
bagi masyarakat Indonesia yang beragama selain Islam, contohnya adalah UU No 1 Tahun 1974 tentang Perkawinan. Di samping Figh al-qanûn, terdapat juga peraturan perundang-undangan positif, jiwanya bisa senafas dengan hukum Islam. Sistem hukum dan kontribusi hukum Islam terhadap sistem hukum nasional Indonesia akan dijelaskan lebih detail di bawah ini.

\section{Sejarah Konstitusi Indonesia dan Kontribusi Hukum Islam}

Bangsa Indonesia sejak proklamasi kemerdekaan hingga sekarang telah mengalami beberapa kali perubahan konstitusi. Beberapa konstitusi yang pernah diberlakukan di Indonesia adalah UUD 1945, Konstitusi Republik Indonesia Serikat, UUD Sementara 1950, kemudian kembali ke UUD 1945 pada tanggal 5 Juli 1959, dan sekarang UUD 1945 reformasi hasil amandemen.

Proses penyusunan UUD 1945 sebagai konstitusi negara Republik Indonesia berjalan sedemikian alot dan penuh dinamika. Naskah awal UUD 1945 dipersiapkan oleh sebuah Badan Penyelidik Usaha-Usaha Persiapan Kemerdekaan Indonesia (BPUPKI). Badan ini dibentuk oleh pemerintah Jepang pada bulan April 1945. Anggota BPUPKI terdiri dari 62 orang bangsa Indonesia dan 6 orang anggota bangsa Jepang (sebagai anggota pasif). Keanggotaan 62 orang berkebangsaan Indonesia sebagian besar diusulkan oleh Soekarno dan Mohammad Hatta ${ }^{15}$. Oleh sebab itu, komposisi anggota BPUPKI lebih dominan dari golongan nasionalis daripada golongan Islam. Menurut Abdul Kahar Muzakkir jumlah anggota BPUPKI yang representatif mewakili golongan Islam hanya sekitar 17 orang dari seluruh anggota. ${ }^{16}$

Sidang pertama BPUPKI difokuskan kepada pembahasan masalah umum pemerintahan: apakah negara yang akan didirikan nantinya berupa eenheid staat, statebond, bondstaat, federasi, monarki, atau negara kesatuan;

${ }_{15}$ Yusril Ihza Mahendra, Dinamika Tatanegara Indonesia: Kompilasi Aktual Masalah Konstitusi, Dewan Perwakilan, dan Sistem Kepartaian, Cet. 1 edition (Jakarta: Gema Insani Press, 1996), h. 63.

${ }^{16}$ Mahendra, Dinamika Tatanegara Indonesia: Kompilasi Aktual Masalah Konstitusi, Dewan Perwakilan, dan Sistem Kepartaian, h. 64. 
apakah kepala negara akan diberei gelar raja, imam atau presiden. ${ }^{17}$ Pada sidang pertama ini terjadi perdebatan sengit antara kelompok nasionalis dan kelompok Islam. Sebagian anggota menginginkan negara integralistik sebagian lagi menginginkan negara agama. KH. Masjkoer mengusulkan supaya dasar Indonesia Merdeka nanti hendaknyalah "Islam", mengingat 90\% rakyat Indonesia beragama Islam. Usul tersebut didukung oleh Abdoel Kahar Moezakkir. Di pihak yang lain Sam Ratulangi dan Latoeharhary menanggapi usulan tersebut dengan singkat namun tegas. Mereka mengancam akan mengundurkan diri dari sidang dan selanjutnya tidak ikut bertanggung jawab lagi apabila BPUPKI menetapkan dasar Indonesia Merdeka adalah Islam. ${ }^{18}$

Rumusan hasil sidang BPUPKI akhirnya diserahkan kepada panitia kecil yang terdiri dari sembilan orang, yaitu Soekarno, Mohammad Hatta, Haji Agus Salim, Abikusno Tjokrosujoso, Abdul Wahid Hasjim, A.A. Maramis, A. Kahar Muzakkir, Ahmad Soebardjo, dan Muhammad Yamin. Hasil rumusan panitia kecil inilah yang kemudian dikenal dengan "Piagam Jakarta" atau "Jakarta Charter". ${ }^{19}$ Rumusan ini yang oleh Muhammad Yamin dan Soekiman Wirjosandjojo dikatakan sebagai gentlemen agreement dan "modus vivendi". ${ }^{20}$

Namun, kompromi ini dimentahkan pada sidang pengesahan oleh PPKI tanggal 18 Agustus 1945. tujuh kata yang terdapat dalam pembukaan UUD 1945 dihapuskan oleh Mohammad Hatta atas keberatan masyarakat Indonesia Timur yang disampaikan oleh seorang opsir Angkatan Laut Jepang, Letnan Kolonel Shegetada Nishijima. Untuk mengganti penghapusan tujuh kata tersebut Ki Bagus Hadikusumo mengusulkan kalimat "Ketuhanan Yang Maha Esa”. Menurutnya, kata-kata itu bermakna tauhid, yaitu ajaran tentang keesaan Tuhan menurut Islam. ${ }^{21}$

${ }^{17}$ S Silalahi, Dasar-Dasar Indonesia Merdeka Versi Para Pendiri Negara (Jakarta: Gramedia Pustaka Utama, 2001), h. 66.

${ }_{18}$ Silalahi, Dasar-Dasar Indonesia Merdeka Versi Para Pendiri Negara, h. 67.

19 Mahendra, Mahendra, Dinamika Tatanegara Indonesia: Kompilasi Aktual Masalah Konstitusi, Dewan Perwakilan, dan Sistem Kepartaian, h. 66.

${ }^{20}$ Mahendra, Mahendra, Dinamika Tatanegara Indonesia: Kompilasi Aktual Masalah Konstitusi, Dewan Perwakilan, dan Sistem Kepartaian, h. 66.

${ }^{21}$ Mahendra, Mahendra, Dinamika Tatanegara Indonesia: Kompilasi Aktual Masalah Konstitusi, Dewan Perwakilan, dan Sistem Kepartaian, h. 66. 
Jika dilihat proses penyusunan konstitusi Indonesia nampak dengan jelas kontribusi hukum Islam.melalui pandangan-pandangan yang disampaikan oleh anggota BPUPKI dari golongan Islam. Namun yang menjadi pertanyaan selanjutnya adalah apakah pembukaan UUD 1945 secara imperatif menentukan isi, arah, dan batasan norma-norma hukum positif di Indonesia?.

Ahli hukum tata negara Indonesia Prof. Notonagoro dengan meminjam kerangka teoritis Hans Kelsen tentang hierarki norma-norma hukum menyatakan bahwa pokok-pokok pikiran yang terkandung di dalam pembukaan UUD 1945 adalah "pokok-pokok kaidah fundamental negara" atau staatfundamentalnorm.

Dengan demikian, kedudukan pembukaan lebih tinggi daripada batang tubuh UUD 1945 maupun peraturan perundang-undangan lainnya. Hal ini disebabkan karena sistem hukum yang dianut Indonesia adalah sistem hukum yang banyak dipengaruhi oleh tradisi hukum Eropa Kontinental. Berbeda halnya kalau dalam sistem hukum Anglo Saxon di mana yang dimaksud dengan law hanyalah pasal-pasal dalam suatu peraturan perundangan tertulis, sedangkan pembukaan tidak merngandung norma, bahkan tidak membawa implikasi juridis terhadap penafsiran pasal-pasal.

\section{Prospek Hukum Islam Pasca Amandemen UUD 1945}

UUD termasuk UUD 1945 meskipun merupakan karya agung tetapi ia bukan kitab suci yang tidak bisa dirubah, apalagi UUD 1945 itu dirancang sementara yang di kemudian hari bisa disempurnakan oleh generasi berikutnya sesuai dengan kebutuhan. Karya manusia bagaimanapun agungnya tetap mengandung ketidaksempurnaan. Moris, seorang peserta dan penanda tangan naskah UUD Amerika Serikat mengatakan: "Nothing human can be perfect. Surrounded by difficulties, we did the best we could; leaving it with those who should come after us to take counsel from experience, and exercise prudently the power of amendment, which we had provided..." Namun meskipun begitu, Moris mengingatkan, agar penggunaan ketentuan mengenai amandemen dipergunakan dengan penuh kearifan dan kehati-hatian. ${ }^{22}$

${ }^{22}$ Bagir Manan, Teori dan Politik Konstitusi (Yogyakarta: FH. UII Press, 2003), h. 1-2. 
Diamandemen tidaknya sebuah konstitusi tidak semata ditentukan oleh ketentuan hukum yang mengatur tata cara perubahan, tetapi lebih ditentukan oleh berbagai kekuatan politik dan sosial yang dominan pada saat-saat tertentu. Wheare mengatakan bahwa mudah atau tidak mudah, sering atau tidak sering suatu UUD diubah: depend not only on legal provisions which prescribe the method of change but also on the predominant political and social groups in the community and the extent to which they are satisfied with or acquiesce in the organization and distribution of political power which to Constitution prescribes. ${ }^{23}$

Dalam konteks negara kebangsaan seperti Indonesia, hukum Islam pada dasarnya baru merupakan bahan mentah (row material), sama halnya dengan hukum adat atau hukum-hukum yang lain. Ketika ada amandemen sebuah konstitusi atau peraturan perundang-undangan yang lain, hukum Islam bisa saja ditransformasikan menjadi hukum positif sejauh bisa disepakati/diterima oleh forum pengambil keputusan publik melalui cara dan prosedur yang demokratis.

Pembentukan hukum nasional bisa dilakukan dengan cara eklektik dari berbagai sumber hukum seperti hukum Islam, hukum adat, dan hukum Barat. Dimaksud eklektik (isme) di sini adalah suatu sistem yang dibentuk dengan, secara kritis, memilih materi (bahan) hukum dari pelbagai sumber dan doktrin. Hukum Islam baik secara juridis maupun operasional merupakan salah satu sumber hukum nasional, di samping sumber lainnya. Upaya untuk menjadikan hukum Islam sebagai sumber hukum yang dominan adalah suatu keniscayaan, baik dilihat dari konsekuensi teologis, kenyataan bahwa Indonesia berdasar Pancasila dan UUD 1945, maupun penduduknya yang mayoritas Muslim.

Lahirnya reformasi total dalam segala bidang di Indonesia menjadi kesempatan dan sekaligus tantangan bagi hukum Islam. Dalam bidang hukum, hukum Islam dapat berperan baik sebagai hukum materil ataupun dalam konteks etika/moralitas hukum. Hanya saja perlu dilakukan perubahan pendekatan yaitu dari yang sebelumnya idealis, melangit dan

${ }^{23}$ Bagir Manan, Teori dan Politik Konstitusi, h. 3. 
tidak membumi menjadi bersifat empiris dan realistis. ${ }^{24}$

Dewasa ini ada sebuah perkembangan yang menggembirakan berkaitan dengan semakin besarnya peran hukum Islam di tengah kehidupan berbangsa dan bernegara di Indonesia khususnya di dalam konteks hukum, semakin banyaknya peraturan perundang-undangan yang bersumber atau paling tidak diinspirasi oleh hukum Islam. Contohnya draft KUHP khususnya delik tentang zina, santet, dan penyebaran ajaran Komunisme/Marxisme-Leninisme. Contoh lainnya yang terbaru adalah RUU Anti Pornografi dan Pornoaksi.

Di samping itu, politik hukum Islam pasca reformasi juga semakin menunjukkan grafik yang menggembirakan. A. Saifuddin mencatat beberapa contoh peraturan perundang-undangan yang semakin mengakomodir kepentingan umat Islam seperti disahkannya beberapa undang-undang, antara lain UU Nomor 17 Tahun 1999 Tentang Penyelenggaraan Ibadah Haji, UU Nomor 38 Tahun 1999 Tentang Pengelolaan Zakat yang sudah diperbaharui dengan UU Nomor 23 tahun 2011, UU nomor 41 tahun 2004 tentang Wakaf dan UU Nomor 18 Tahun 2001 Tentang Otonomi Khusus Propinsi Daerah Istimewa Aceh. ${ }^{25}$

Berharap bahwa hukum Islam secara keseluruhan akan dipositifkan dan menjadi mazhab negara juga tidak mungkin. Oleh karena itu, harus ada pemilahan ajaran-ajaran Islam dalam beberapa tingkatan dengan domain yang berbeda-beda; pada saat yang sama bagaimana negara mesti menyikapi juga bisa berbeda-beda. Pertama, ajaran keyakinan (akidah) kepada Allah Yang Esa, malaikat, para Rasul dan hari kiamat, dan sebagainya. Keyakinan-keyakinan seperti ini adalah perkara yang benarbenar personal. Bahkan keyakinan sesama umat Islam sendiri perihal Tuhannya bisa berbeda satu dengan yang lain. Dalam hal ini negara bukan saja harus terpisah, bahkan tidak punya kemampuan apa-apa untuk menjangkaunya. Perlakuan negara terhadap warga semata-mata berdasarkan faktor keyakinan pribadi seperti ini benra-benar tidak pada tempatnya, dan harus ditolak.

${ }^{24}$ Ahmad Qodri Abdillah Azizy dan Busthanul Arifin, Eklektisisme Hukum Nasional: Kompetisi Antara Hukum Islam dan Hukum Umum, Cet. 1 (Yogyakarta: Gama Media, 2002), h. 251.

${ }^{25}$ M. Shohibul Itmam, 'Hukum Islam dalam Pergumulan Politik Hukum Nasional Era Reformasi', Al-Tahrir: Jurnal Pemikiran Islam, 13.2 (2013): h. 73-96. 
Kedua, ajaran dan praktek keagamaan (ubûdiyah) yang bersifat khas keumatan seperti soal bagaimana salat atau haji dilaksanakan, kapan dan di mana, sepenuhnya merupakan urusan intern umat yang bersangkutan. Masuk dalam kategori ini adalah hukum keluarga (al-ahwal al-syakhsiyah). Negara, dengan dalih apa pun, misalnya "persatuan umat", tidak boleh campur tangan terhadap urusan ini. Intervensi negara/pemerintah RI yang selama ini terjadi dalam urusan peribadatan seperti penentuan hari raya atau urusan pernikahan, misalnya, adalah salah kaprah yang harus segera diakhiri.

Ketiga, ajaran keagamaan (Islam) yang bersifat publik. Misalnya ajaran-ajaran Islam tentang hukum-hukum mu'âmalat (hukum dagang), aturan perbendaharaan negara (dari mana dana negara digali dan untuk kepentingan siapa/apa dibelanjakan), serta hukum-hukum jinâyat (pidana). Ajaran Islam kategori ini, meskpun sifatnya publik, tidak bisa dengan serta merta diberlakukan sebagai hukum positif. Jangankan dalam negara kebangsaan yang plural seperti Indonesia, dalam negara Islam pun hukum Islam perlu diobyektivikasikan melalui forum pengambilan keputusan publik (parlemen), karena perbedaan mazhab yang pasti beragam seputar isu-isu tersebut. ${ }^{26}$

\section{Prospek Hukum Islam dalam Otonomi Daerah}

Sistem pemerintahan pada masa Orde Baru yang sangat sentralistik dan hegemonik telah melahirkan ketidakadilan dan ketidakmerataan sosial ekonomi terutama bagi daerah-daerah yang jauh dari pusat kekuasaan. Oleh karena itu, sejak bergulirnya era reformasi tuntutan untuk mengganti sistem yang sentralistik menjadi desentralistik menjadi sesuatu yang niscaya. Untuk memenuhi aspirasi reformasi tersebut DPR dan pemerintah telah mengesahkan UU Nomor 22 Tahun 1999 Tentang Otonomi Daerah yang kemudian direvisi dengan UU Nomor 32 Tahun 2004.

Otonomi daerah sebagai konsekuensi logis dari desentralisasi, berimbas pada tuntutan pembuatan aturan hukum lokal sesauai dengan yuridiksi yang harus dibuat sesuai dengan substansi hukum, budaya

${ }^{26}$ Masdar Farid Mas'udi, Syarah UUD 1945 Perspektif Islam (Pustaka Alvabet, 2013), h. 4. 
hukum, dan struktur hukum yang sesuai dengan esensi hukum yaitu keadilan dan proporsionalitasnya. ${ }^{27}$

Reformasi merupakan momentum pemberlakuan dan penerapan syariat Islam. Peluang penerapan syariat juga menemukan momentum bagus berkenaan dengan krisis yang dialami oleh Indonesia, yang berawal dari krisis moneter, kemudian berkembang menjadi krisis ekonomi, politik, sosial dan krisis kepercayaan. Di balik itu semua, sebenarnya krisis ini juga bisa dikatakan sebagai berkah terselubung (blessing indisguise). Dengan adanya krisis ini mulai tersingkap kelemahan sistem sosial, ekonomi, politik, dan hukum sekular yang selama ini dianut oleh bangsa Indonesia.

Oleh karena itu, pada situasi semacam itu, hukum Islam dapat menjadi alternatif utama dalam pembuatan aturan hukum lokal (perda) terutama di daerah-daerah yang masyarakatnya memiliki tradisi dan spirit yang sangat kuat untuk menjadikan hukum Islam (syariah) sebagai hukum positif yang berlaku di daerahnya masing-masing. Tidak heran kalau di daerah-daerah seperti Aceh, Banten, Pamekasan Madura, Gorontalo dan daerah-daerah lainnya mulai memberlakukan syariat Islam.

Pemberlakuan syariat Islam di berbagai daerah dalam perspektif demokrasi tentu tidak bisa dihalang-halangi dengan catatan masyarakat di daerah tersebut memiliki political will dan telah mencapai kesepakatan bersama (ijma') untuk menjadikan syariat Islam sebagai hukum positif yang harus diikuti, karena dalam rumus demokrasi sebuah keputusan itu berdasarkan suara terbanyak. Hanya persoalannya kemudian bagaimana kalau suatu peraturan daerah (perda) bertentangan dengan undang-undang yang lebih tinggi, padahal dalam sistem hukum Indonesia terdapat istilah tertib hukum, yaitu peraturan yang lebih rendah tidak boleh bertentangan dengan peraturan di atasnya. Untuk menjawab tantangan ini semestinya para pakar hukum dan tata negara melakukan pengkajian serius tanpa kemudian mengesampingkan aspirasi kelompok masyarakat bahkan merupakan kelompok mayoritas untuk menjadikan hukum Islam sebagai hukum positif sebagai acuan dalam kehidupan bermasyarakat, berbangsa dan bernegaranya.

${ }^{27}$ Artidjo Alkostar, Identitas Hukum Nasional (Fakultas Hukum, Universitas Islam Indonesia, 1997), h. 5. 


\section{Penutup}

Alquran ketika berbicara tentang hukum dan perundang-undangan memang tidak terlalu dominan di dalam ayat-ayat Alquran, hanya 5,8 persen. Hal ini bukanlah kelemahan dari Alquran, tetapi justeru lebih fleksibel membuat peraturan perundang-undangan yang dibutuhkan. Meskipun demikian, Alquran (Islam) dapat menjadi sumber hukum dan sumber nilai dari suatu peraturan yang ada di suatu negara berpenduduk mayoritas muslim, bahkan tidak menutup kemungkinan produk hukum positif seratus persen pada hakikatnya adalah hukum yang diambil dari ajaran Islam.

Di negara yang plural seperti Indonesia tidak dijadikannya agama sebagai dasar negara tetapi hanya sebatas menjadikannya sumber dan bahan (material) merupakan sebuah keputusan yang bijaksana. Memiliki dua keuntungan, yaitu bisa tetap mempertahankan keutuhan dan persatuan bangsa yang plural dan bisa tetap memperjuangkan syari'at Islam untuk diterapkan sebagai hukum positif dengan dasar kesepakatan bersama.

Sejarah telah membuktikan bahwa sejak awal negara ini berdiri hukum Islam telah memiliki posisi yang penting dan telah memberikan kontribusi besar bagi pembentukan dan pengembangan sistem hukum nasional, apalagi pasca reformasi dan pemberlakuan sistem desentralisasi. Reformasi telah menghasilkan keputusan politik yang sangat penting yakni dihapuskannya asas tunggal Pancasila sebagai satu-satunya asas organisasi sosial politik. Reformasi juga telah membuka tabir kelemahan sistem sosial, politik, ekonomi, hukum dan lain sebagainya. Reformasi secara tidak langsung memberikan angin segar bagi digunakannya hukum Islam sebagai alternatif. Demikian halnya juga dengan pemberlakuan desentralisasi. Hukum Islam bisa dijadikan sebagai bahan peraturan daerah yang mengakomodasi kebijakan lokal (local wisdom).

\section{Pustaka Acuan}

Abu Zahra, Muhammad. Usul Al-Fiqh. Cairo: Dâr al-Fikr al-'Arabi, 1958. Abrori, Ahmad. "Refleksi Teori Kritis Jurgen habermas atas Konsesus Simbolik Perda Syariah.” Ahkam: Jurnal Ilmu Syariah 16, no. 1 (2016). 
Afzal, Mohammad, and Qaisar Abbas. "Wagners Law in Pakistan: Another Look." Journal of Economics and International Finance 2, no. 1 (2009): 012-019.

Ahmad, Munawar. "Fenomena Perda Syariah: Institutional Identitas pada Tingkat Local State.” Jurnal Sosiologi Agama 1, no. 1 (2007).

Alim, Muhammad. "Perda Bernuansa Syariah dan Hubungannya dengan Konstitusi." Jurnal Hukum Ius Quia Iustum 17, no. 1 (2010): 119-142. Alkostar, Artidjo. Identitas Hukum Nasional. Yogyakarta: Fakultas Hukum, Universitas Islam Indonesia, 1997.

Anderson, James Norman Dalrymple. "The Modernisation of Islamic Law in the Sudan." Sudan Law Journal and Reports1960 (1960): 292-312. Azizy, Ahmad Qodri Abdillah, dan Busthanul Arifin. Eklektisisme Hukum Nasional: Kompetisi Antara Hukum Islam dan Hukum Umum. Yogyakarta: Gama Media, 2002.

Bendak, Salaheddine. "Compliance With Seat Belt Enforcement Law in Saudi Arabia." International Journal of Injury Control and Safety Promotion 14, no. 1 (2007): 45-48.

Bush, Robin. "10 Regional Sharia Regulations In Indonesia: Anomaly Or Symptom?." Expressing Islam: Religious life and politics in Indonesia (2008): 174.

Candraningrum, Dewi. "Unquestioned Gender Lens in Contemporary Indonesian Shari 'ah-Ordinances (Perda Syariah)." Al-Jamiah: Journal of Islamic Studies 45, no. 2 (2007): 289-320.

Cohen, Jennifer F. "Islamic Law in Iran: Can It Protect the International Legal Right of Freedom of Religion and Belief." Chi. J. Int'l L. 9 (2008): 247. Coulson, Noel J. "Reform of Family Law in Pakistan." Studia Islamica 7 (1957): 135-155.

David. 'Konsep Hukum dalam Alquran: Keadilan dan Kemanusiaan', Tahkim, (2009).

Faroqi, A. "Analisis Ayat-ayat Mutasyabihat Tafsir Al-Munir Karya Wahbah Az-Zuhaili.” PhD diss., UIN Walisongo, 2016.

Farmanfarma, Amir. "Constitutional Law of Iran." The American Journal of Comparative Law (1954): 241-247. 
Firdausi, Muhammad Anwar. "Membincang Ayat-ayat Muhkam dan Mutasyabih." Ulul Albab Jurnal Studi Islam 16, no. 1 (2015): 80-88. Fluehr-Lobban, Carolyn. Islamic Law and Society in the Sudan. Routledge, 2013.

"Islamization in Sudan: A Critical Assessment." Middle East Journal 44, no. 4 (1990): 610-623.

Gravelle, Kent Benedict. "Islamic Law in Sudan: A Comparative Analysis.” ILSA J. Int'l \& Comp. L. 5 (1998): 1.

Hadi Ismail M, Hadi. "Konsep Tauriyah dalam Memahami Ayat-ayat Mutasyabihat: Studi Analisis terhadap Ta’wiil Ayat-ayat Sifat." PhD diss., UIN Sunan Gunung Djati Bandung, 2012.

Haika, Ratu. "Konsep Qath'i dan Zhanni dalam Hukum Kewarisan Islam." Mazahib 15, no. 2 (2016): 182-195.

Hamlin, Kristan L. Peters. "The Impact of Islamic Revivalism on Contract and Usury Law in Iran, Saudi Arabia, and Egypt.” Tex. Int'l LJ 22 (1987): 351.

Hanafi, Ahmad. Pengantar dan Sedjarah Hukum Islam. Jakarta: Bulan Bintang, 1970.

Itmam, M. Shohibul. 'Hukum Islam dalam Pergumulan Politik Hukum Nasional Era Reformasi', Al-Tahrir: Jurnal Pemikiran Islam, 13 (2013): 273-96.

Jati, Wasisto Raharjo. "Permasalahan Implementasi Perda Syariah dalam Otonomi Daerah." Al-Manahij: Jurnal Kajian Hukum Islam 7, no. 2 (2013): 305-318.

Kar, Mehrangis. "Schari'a Law in Iran." Radical Islam's Rules: The Worldwide Spread of Extreme Sharia Law (2005): 41-64.

Kamil, Sukron, Andy Agung Prihatna, Karina Helmanita, J. M. Muslim, Ridwan al-Makassary, Aang Abu Bakar, and Tuti Alawiyah. Syariah Islam dan HAM: Dampak Perda Syariah Terhadap Kebebasan Sipil, Hak-hak Perempuan dan Non-Muslim. Center for the Study of Religion and Culture (CSRC) UIN Syarif Hidayatullah Jakarta, 2007. , dan C. S. Bamualim. "Syariah Islam dan HAM: Dampak Perda Syariah terhadap Kebebasan Sipil, Hak-Hak Perempuan, dan 
Non-Muslim [Shari'a and Human Rights: The Impacts of Local Regulations to the Civil Freedom, the Rights of Women, and nonMuslims]." Jakarta: CSRC UIN Jakarta \& KAS Jakarta (2007).

Kamali, Mohammad Hashim. "Punishment in Islamic law: A critique of the hudud bill of Kelantan, Malaysia." Arab Law Quarterly 13, no. 3 (1998): 203-234.

Larijani, Bagher, and Farzaneh Zahedi. "Health Promotion, Islamic Ethics and Law in Iran." DARU Journal of Pharmaceutical Sciences Suppl. 1 (2006): 7-9.

Layish, Aharon, and Gabriel R. Warburg. The Reinstatement of Islamic law in Sudan Under Numayrî: An Evaluation of A Legal Experiment in the Light of Its Historical Context, Methodology, and Repercussions. Brill, 2002.

Lombardi, Clark B. "Islamic Law As A Source of Constitutional Law in Egypt: The Constitutionalization of the Sharia in A Modern Arab State." Colum. J. Transnatl L. 37 (1998): 81. , State Law as Islamic Law in Modern Egypt: The Incorporation of the Sharîa into Egyptian Constitutional Law. Brill, 2006.

Mahendra, Yusril Ihza. Dinamika Tata Negara Indonesia: Kompilasi Aktual Masalah Konstitusi, Dewan Perwakilan, dan Sistem Kepartaian. Jakarta: Gema Insani Press, 1996.

Manan, Bagir. Teori dan Politik Konstitusi. Yogyakarta: FH. UII Press, 2003.

Mas'udi, Masdar Farid. Syarah UUD 1945 Perspektif Islam. Jakarta: Pustaka Alvabet, 2013.

Mir-Hosseini, Ziba. "8 Sharia and National Law in Iran." Sharia Incorporated (2010): 319.

Mehdi, Rubya. "The Offence of Rape in the Islamic Law of Pakistan." Women Living under Muslim Laws: Dossier 18 (1997): 98-108. , The Islamization of the Law in Pakistan (RLE Politics of Islam). Routledge, 2013.

Munawwir, Ahmad Warson. Kamus Al-Munawwir Arab-Indonesia Terlengkap. Surabaya: Pustaka Progressif, 1997. 
Moustafa, Tamir. "Islamic Law, Women's Rights, and Popular Legal Consciousness in Malaysia." Law \& Social Inquiry 38, no. 1 (2013): 168-188.

Muqoddas, Hj Djazimah, dan M. SH. Kontroversi Hakim Perempuan pada Peradilan Islam di Negara-negara Muslim. Yogyakarta: LKiS Pelangi Aksara, 2011.

Moustafa, Tamir. "Judging in God's Name: State Power, Secularism, and the Politics of Islamic Law in Malaysia." Oxford Journal of Law and Religion 3, no. 1 (2013): 152-167.

Nahar, Syamsu. "Keberadaan Ayat Muhkam dan Mutasyabih dalam AlQuran.” Nizhamiyah 6, no. 2 (2016).

Nasution, Harun. Islam Ditinjau dari Berbagai Aspeknya Jilid 1. Depok: Penerbit UI-Press, 2013.

Nasution, Khoiruddin. Status Wanita di Asia Tenggara: Studi Terhadap Perundang-undangan Perkawinan Muslim Kontemporer di Indonesia dan Malaysia. Vol. 39. INIS, (2002). , Islam Tentang Relasi Suami dan Isteri (Hukum Perkawinan I): Dilengkapi Perbandingan UU Negara Muslim. Yogyakarta: ACAdeMIA, 2004.

Niknam, Azadeh. "The Islamization of Law in Iran." Middle East Report 29, no. 212 (1999): 17-21.

Pahlavani, Mosayeb, Davoud Abed, and Farshid Pourshabi. "Investigating the Keynesian View and Wagner's Law on The Size Of Government And Economic Growth In Iran.” International Journal of Business and Social Science 2, no. 13 (2011).

Permata, Ahmad Norma. "Perda Syariah Islam, Rekayasa Institusional dan Masa Depan Demokrasi.” dalam Jurnal Ijtihad 7, no. 1 (2007).

Purnomo, Agus. "Politik Hukum Elite Politik Kabupaten Pamekasan Tentang Perda Syariat.” Istinbath: Jurnal Hukum Islam IAIN Mataram 13, no. 1 (2013).

Rahiem, Husni. Perkembangan Ilmu Fiqh di Dunia Islam. Jakarta: Depag RI, 1991.

Subhan. "Klasifikasi Ayat-ayat Hukum (dari Segi Qathi dan Zhanni).” Mazahib 12, no. 2 (2013). 
Silalahi, S. Dasar-dasar Indonesia Merdeka Versi Para Pendiri Negara. Jakarta: Gramedia Pustaka Utama, 2001.

Shuaib, Farid Sufian, Tajul Aris Ahmad Bustami, Mohd Kamal, and Mohd Hisham. Administration of Islamic law in Malaysia: Text and Material. Malayan Law Journal, 2001.

Suharso, Pudjo. "Pro Kontra Implementasi Perda Syariah (Tinjauan Elemen Masyarakat).” Al-Mawarid 16 (2006).

Souryal, Sam S. "The Religionization of A Society: The Continuing Application of Shariah Law in Saudi Arabia." Journal for the Scientific Study of Religion (1987): 429-449.

Umar, Nasaruddin, dan Direktur Jenderal Bimbingan Masyarakat Islam. "Hukum Keluarga Kontemporer di Negara-negara Muslim." Dalam Makalah Seminar Nasional Hukum Materiil Peradilan Agama antara Cita, Realitas dan Harapan, Hotel Red Top Jakarta, vol. 19. 2010

Vogel, Frank E. Islamic Law and the Legal System of Saudi: Studies of Saudi Arabia. Vol. 8. Brill, (2000).

Walsh, Lawrence E. "Political Oversight, the Rule of Law, and IranContra." Clev. St. L. Rev. 42 (1994): 587.

Yanti, Nova. "Memahami Makna Muhkamat dan Mutasyabihat dalam Al-Quran." Al-Ishlah: Jurnal Pendidikan 8, no. 2 (2016): 246-256. Zaelani, Abdul Qodir. "Konsep Ta'aqquli dan Ta'abbudi dalam Konteks Hukum Keluarga Islam.” Asas: Jurnal Hukum dan Ekonomi Islam 6, no. 1 (2014). 